Dhaka Univ. J. Biol. Sci. 28(1): 93-110, 2019 (January)

\title{
PHOSPHATE SORPTION INDICES AS AFFECTED BY THE CALCAREOUSNESS OF SOILS
}

\author{
Tasmeena Sultana Yousuf ${ }^{1}$, Mohammad Enayet Hossain*, \\ MOHAMMAd Zafar Afsar ${ }^{1}$ AND KHAN TOWHID OSMAN ${ }^{1}$ \\ Department of Soil, Water and Environment, University of Dhaka, Dhaka-1000, Bangladesh
}

Key words: Phosphate sorption indices, Calcareousness, Phosphorus buffering capacity, Standard phosphorus requirement

\begin{abstract}
An experiment was carried out to study the effects of calcareousness on phosphate sorption indices of soils using three representative calcareous soils, namely Sara (Aquic Eutrochrept), Gopalpur (Aquic Eutrochrept), and Ishurdi (Aeric Haplaquept) series of Bangladesh. Three non-calcareous soils, namely Belabo (Typic dystrudepts), Sonatala (Aeric Endoaquepts) and Ghatail (Aeric Haplaquept) series were also selected for comparison purposes. Phosphate sorption indices of soils were calculated using Langmuir and Freundlich isotherms. Isotherms were constructed taking one gram of air-dried sieved $(<2$ $\mathrm{mm}$ ) soil into a $50 \mathrm{ml}$ centrifuge tube, and subsequently adding seven initial $\mathrm{P}$ concentrations, namely $0,1,10,25,50,100$ and $150 \mu \mathrm{g} / \mathrm{ml}$ to each centrifuge tube employing a soil/solution ratio of $1: 20(\mathrm{w} / \mathrm{N})$. According to the Langmuir equation, the amount of phosphate sorbed followed the order: Sonatala $>$ Ghatail $>$ Sara $=$ Gopalpur $>$ Ishurdi $>$ Belabo. The abundance of amorphous iron rather than the calcareousness was putatively responsible for the high phosphate sorption capacity of soils. Maximum phosphorus buffering capacity (MPBC) of the calcareous soils ranged from 33.4 - $62.81 / \mathrm{kg}$. Langmuir and Freundlich equations produced different values for soil $P$ requirements (SPR) at 0.2 and 1.0 mg P A. Calcareous soils would require 27 - $44 \mathrm{mg}$ P/kg soil to attain $0.2 \mathrm{mg}$ P 1 soil solution, which is deemed sufficient for crop growth. The soils would require 32 - $58 \mathrm{mg} \mathrm{P} / \mathrm{kg}$ soil to reach $1.0 \mathrm{mg} \mathrm{P} / \mathrm{s}$ soil solution, which is regarded to be safe for soils in terms of susceptibility to P losses. The calculated Langmuir constant $b$ values were higher than the threshold value of $0.071 / \mathrm{mg}$ for two of the calcareous soils. Therefore, even though the non-calcareous soils sorbed more phosphate, higher bonding energy of $\mathrm{P}$ sorption for calcareous soils makes them less vulnerable to loss via surface runoff.
\end{abstract}

*Author for correspondence: <enayetswe@du.ac.bd>. ${ }^{1}$ Department of Soil Science, University of Chittagong, Chittagong-4331, Bangladesh. 


\section{Introduction}

Soil phosphorus (P) concentrations in an optimum range for plant growth is absolutely vital to sustain soil fertility and ensure the production of food crops. Phosphorus is therefore applied to agricultural fields as inorganic and/or organic fertilizers. However, $\mathrm{P}$ is a nonrenewable resource and a recent assessment indicated that natural phosphate $\left(\mathrm{PO}_{4}{ }^{3-}\right)$ deposits will last for approximately $60-240$ years ${ }^{(1)}$. Therefore, judicious use of existing phosphate resource is absolutely necessary to ensure the longterm availability and accessibility of phosphorus sources for the present and future generations of humankind ${ }^{(2)}$.

On the other hand, the amount of fertilizer applied often exceeds the uptake by plants, and this results in a build-up of $\mathrm{P}$ in the soil. A fraction of applied $\mathrm{P}$ is lost through surface runoff and leaching processes and the lost $\mathrm{P}$ constitute the major nonpoint source of phosphorus in water bodies ${ }^{(3)}$. Elevated levels of $\mathrm{P}$ in freshwater systems leads to eutrophication, which results in the depletion of oxygen leading to fish death as well as affecting other aquatic life forms in an adverse manner. Therefore, the amount of $\mathrm{P}$ in waters should be curtailed to prevent eutrophication in lakes and other surface waters ${ }^{(4)}$.

Since the concentration of $\mathrm{P}$ in the soil solution is critical for losses of dissolved $\mathrm{P}$, processes such as $\mathrm{P}$ sorption and desorption are crucial. Sorption isotherm is an important tool for investigating the sorption behavior of soils. Phosphorus sorption isotherm has an edge over conventional soil $\mathrm{P}$ test because conventional soil tests do not take into account the physicochemical properties of soils ${ }^{(5)}$. Models such as Langmuir, Freundlich, and Temkin are commonly used for describing phosphate sorption in quantitative terms, and different sorption parameters derived from these models are subsequently correlated with different soil parameters for validation. For example, the amount of $\mathrm{P}$ required, soil phosphorus requirements $\left(\mathrm{P}_{\mathrm{req}}\right)$, to bring its desired concentration in soil solution could easily be determined by $\mathrm{P}$ sorption isotherm ${ }^{(6,7)}$.

Soil $\mathrm{P}$ requirements are determined by plugging in the desired $\mathrm{P}$ concentrations into the fitted sorption equations. Intended land use dictates the value of choice for the $\mathrm{P}$ concentration. For example, $0.2 \mathrm{mg} \mathrm{P} A$ is considered to be the standard solution concentration for most field crops $^{(8)}$, whereas $1 \mathrm{mg} \mathrm{P} A$ is the maximum level of $\mathrm{P}$ concentration in surface runoff when water quality is the concern ${ }^{(9)}$. These predetermined concentrations are called standard phosphorus requirements (SPR). Another quantity calculated from the model is maximum phosphate buffering capacity (MPBC), which gives an idea as to how much fertilization will be required to maintain a predetermined concentration of $\mathrm{P}$.

In Bangladesh, calcareous soil occupies $\sim 19 \%$ area of the country(10). Very few researches have been done on the phosphate sorption characteristics of the soils which are calcareous in nature. Therefore, a study was undertaken to investigate the effects of 
calcareousness on the phosphate sorption properties of three calcareous soils. More specifically, phosphate sorption indices, namely standard phosphorus requirements (SPR) and maximum phosphate buffer capacities (MPBC) were looked at along with other sorption parameters. Some selected soil properties were studied to see how they influence the sorption properties of soils along with calcareousness. Some non-calcareous soils were also studied for comparison purposes.

\section{Materials and Methods}

Soil selection and sample collection: Six representative soil series, including three calcareous, namely Sara, Gopalpur, Ishurdi, and three non-calcareous, namely Belabo, Sonatala and Ghatail of Bangladesh, were selected for this study (Table 1). Sara, Gopalpur and Ishurdi series were collected from Ishurdi Upazila of Pabna district, Bangladesh. Soil samples of Belabo, Sonatala and Ghatail series were collected from Ghatail of Tangail district, Bangladesh. The general type and taxonomic classification of the soils are given in Table 1. Composite sampling technique was adopted for collecting the soil samples. Six composite samples representing six soil series were made up of 20 spots from an area of $1 \mathrm{~km}^{2}$. Only surface soil $(0-15 \mathrm{~cm})$ was collected for the study. The collected soil samples were taken to the lab, and the crop residues and other non-soil materials were then carefully removed. Thereafter, the soil samples were air dried, ground and sieved through a $2 \mathrm{~mm}$ (10-mesh) sieve.

Analysis of soil physical and chemical properties: Particle size distribution was determined by a hydrometer method(11). Soil $\mathrm{pH}$ was measured by Jenway Glass Electrode $\mathrm{pH}$ meter using a $1: 2.5$ soil to water ratio. The chemical parameters were determined following different widely used and some specific methods. Free carbonate of the calcareous soil samples was determined using rapid titration method ${ }^{(12)}$. Soil organic carbon was determined by Walkley-Black wet oxidation method(13). Soil organic matter was calculated by multiplying the per cent value of organic carbon by the van Bemmelen conversion factor of 1.724. Cation exchange capacity (CEC) was determined using a neutral $1 \mathrm{M} \mathrm{NH}_{4} \mathrm{OAc}$ solution as described by Jackson(14). Total Fe and $\mathrm{Mn}$ were determined by digesting the soil samples with $\mathrm{HNO}_{3}-\mathrm{HClO}_{4}$ acid and then measuring by flame atomic absorption spectroscopy (AAS) with an Agilent Technologies 200 series AA. Total phosphorus in $\mathrm{HNO}_{3}-\mathrm{HClO}_{4}$ acid digest was determined by using a UV-Vis spectrophotometer (Optima SP-3000 nano, Tokyo, Japan) employing the vanadomolybdate yellow color method as described by Jackson ${ }^{(14)}$. Extraction of available $\mathrm{P}$ was made by $0.5 \mathrm{M} \mathrm{NaHCO}_{3}$ at $\mathrm{pH}$ 8.5(15) and Bray and Kurtz P-1 extracting solution $\left(0.025 \mathrm{M} \mathrm{HCl} \text { in } 0.03 \mathrm{M} \mathrm{NH}_{4} \mathrm{~F}\right)^{(16)}$. Phosphorus in the extract was determined by a UV-Vis spectrophotometer (Optima SP-3000 nano, Tokyo, Japan) following the ascorbic acid blue color method ${ }^{(17)}$. Some fractions of soil Fe have been extracted and determined following selective dissolution procedures. Total or free iron oxide was extracted using citratedithionite reagent ${ }^{(18)}$. Poorly crystalline or active iron oxide was extracted using $\mathrm{NH}_{4-}$ 


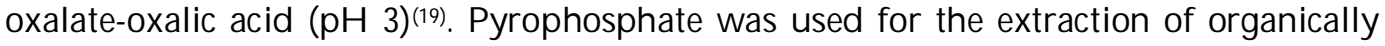
bound Fe. The extracts obtained from different Fe fractions were preserved and finally determined by flame atomic absorption spectroscopy (AAS) with an Agilent Technologies 200 series AA. All determinations were done in triplicate.

Table 1. Present land type, topography and drainage conditions of the soil series and correlation with different soil classification systems ${ }^{(10)}$.

\begin{tabular}{|c|c|c|c|c|c|}
\hline $\begin{array}{l}\text { Series } \\
\text { name }\end{array}$ & $\begin{array}{l}\text { Land type and } \\
\text { parent material }\end{array}$ & Topography & Drainage & $\begin{array}{l}\text { General soil } \\
\text { type }\end{array}$ & $\begin{array}{l}\text { USDA soil } \\
\text { family }\end{array}$ \\
\hline Sara & $\begin{array}{l}\text { High land, } \\
\text { Ganges river } \\
\text { alluvium }\end{array}$ & $\begin{array}{l}\text { Nearly level to } \\
\text { very gently } \\
\text { undulating }\end{array}$ & $\begin{array}{l}\text { Poorly } \\
\text { drained }\end{array}$ & $\begin{array}{l}\text { Calcareous } \\
\text { brown } \\
\text { floodplain } \\
\text { soil }\end{array}$ & $\begin{array}{l}\text { Aquic } \\
\text { Eutrochrept }\end{array}$ \\
\hline Gopalpur & $\begin{array}{l}\text { Medium high } \\
\text { land, Ganges } \\
\text { river alluvium }\end{array}$ & $\begin{array}{l}\text { Nearly level to } \\
\text { gently undulating } \\
\text { upper and middle } \\
\text { slopes }\end{array}$ & $\begin{array}{l}\text { Poorly } \\
\text { drained }\end{array}$ & $\begin{array}{l}\text { Calcareous } \\
\text { brown } \\
\text { floodplain } \\
\text { soil }\end{array}$ & $\begin{array}{l}\text { Aquic } \\
\text { Eutrochrept }\end{array}$ \\
\hline Ishurdi & $\begin{array}{l}\text { Medium high } \\
\text { land, Ganges } \\
\text { river alluvium }\end{array}$ & $\begin{array}{l}\text { Nearly level to } \\
\text { gently undulating } \\
\text { old, low } \\
\text { abandoned levees }\end{array}$ & $\begin{array}{l}\text { Poorly } \\
\text { drained }\end{array}$ & $\begin{array}{l}\text { Calcareous } \\
\text { dark grey } \\
\text { floodplain } \\
\text { soil }\end{array}$ & $\begin{array}{l}\text { Aeric } \\
\text { Haplaquept }\end{array}$ \\
\hline Belabo & $\begin{array}{l}\text { High land, } \\
\text { Madhupur clay }\end{array}$ & Nearly level & $\begin{array}{l}\text { Well } \\
\text { drained }\end{array}$ & $\begin{array}{l}\text { Deep red- } \\
\text { brown } \\
\text { terrace soil }\end{array}$ & $\begin{array}{l}\text { Typic } \\
\text { Dystrudepts }\end{array}$ \\
\hline Sonatala & $\begin{array}{l}\text { High land, Old } \\
\text { Brahmaputra } \\
\text { alluvium }\end{array}$ & $\begin{array}{l}\text { Developed on the } \\
\text { upper slopes of } \\
\text { ridges }\end{array}$ & $\begin{array}{l}\text { Imperfectly } \\
\text { to poorly } \\
\text { drained }\end{array}$ & $\begin{array}{l}\text { Non- } \\
\text { calcareous } \\
\text { dark grey } \\
\text { floodplain } \\
\text { soil }\end{array}$ & $\begin{array}{l}\text { Aeric } \\
\text { Endoaquepts }\end{array}$ \\
\hline Ghatail & $\begin{array}{l}\text { Medium high } \\
\text { land, Old } \\
\text { Brahmaputra } \\
\text { alluvium }\end{array}$ & $\begin{array}{l}\text { Nearly level } \\
\text { basin }\end{array}$ & $\begin{array}{l}\text { Poorly } \\
\text { drained }\end{array}$ & $\begin{array}{l}\text { Non- } \\
\text { calcareous } \\
\text { dark grey } \\
\text { floodplain } \\
\text { soil }\end{array}$ & $\begin{array}{l}\text { Aeric } \\
\text { Haplaquept }\end{array}$ \\
\hline
\end{tabular}

Sorption experiment: Phosphorus sorption isotherms were obtained according to the procedure outlined by Nair ${ }^{(20)}$. One gram of air-dried sieved $(<2 \mathrm{~mm})$ soil was taken into a $50 \mathrm{ml}$ centrifuge tube. Seven initial $P$ concentrations, namely $0,1,10,25,50,100$ and 150 $\mu \mathrm{g} / \mathrm{ml}$ were first prepared in $0.01 \mathrm{M} \mathrm{CaCl}_{2}$ solution using $\mathrm{KH}_{2} \mathrm{PO}_{4}$ salt and then the prepared solutions were added separately to each centrifuge tube using a soil/solution ratio of $1: 20(\mathrm{w} / \mathrm{N})$. The resultant $\mathrm{P}$ contents were $0,20,200,500,1000,2000$ and 3000 
$\mu \mathrm{g} / \mathrm{g}$ soil. The centrifuge tubes were then shaken for $16 \mathrm{hrs}$ to achieve equilibrium. After the equilibration period, the soils were centrifuged, and the phosphate contents were analyzed in the supernatants following the ascorbic acid blue color method(17). Phosphorus content was measured by a UV-Vis spectrophotometer (Optima SP-3000 nano, Tokyo, Japan) at $882 \mathrm{~nm}$ wavelength. The amount of sorbed $\mathrm{P}$ was calculated from the difference between the concentration of soluble $\mathrm{P}$ added in the initial solution and the concentration of $\mathrm{P}$ in the solution at equilibrium. All isotherms were performed in triplicate.

Sorption parameters were calculated using the most common isotherms, namely Langmuir and Freundlich. The Langmuir adsorption model (Eq. 1)(21) is based on the assumption that all the adsorption sites have equal adsorbate affinity and adsorption at one site is independent of the adsorption at an adjacent site. Maximum adsorption corresponds to a saturated monolayer of solute molecules on the adsorbent surface, with no lateral interaction between the adsorbed molecules. The bonding to the adsorption sites can be either chemical or physical but strong enough to prevent displacement of the adsorbed molecules.

$$
q_{e}=\frac{Q_{0} b C_{e}}{1+b C_{e}}
$$

where $C_{g}\left(\frac{\mathrm{mg}}{\mathrm{L}}\right)$ is the equilibrium concentration of the remaining ions in the solution; $q_{e}\left(\frac{\mathrm{mg}}{\mathrm{kg}}\right)_{\text {is }}$ the amount of ions adsorbed per mass unit of adsorbent at equilibrium; $Q_{0}\left(\frac{\mathrm{mg}}{\mathrm{kg}}\right)$ is the amount of ions at complete monolayer, and $b\left(\frac{\mathrm{L}}{\mathrm{mg}}\right)$ is the Langmuir constant related to the affinity of binding sites which is a measure of the energy of adsorption. The Langmuir equation can be described by the linearized form:

$$
\frac{C_{e}}{Q_{e}}=\frac{1}{Q_{0}} C_{e}+\frac{1}{Q_{0} b}
$$

The Langmuir constants $Q_{0}$ and $b$ were calculated from the slope and intercept of the plots of $\frac{C_{t}}{Q_{t}}$ (Y-axis) and $C_{t}(\mathrm{X}$-axis).The maximum phosphorus buffering capacity $(\mathrm{MPBC})$ of the soil (the increase in sorbed $\mathrm{P}$ per unit increase in final solution $\mathrm{P}$ concentration), was estimated from the product of Langmuir constants $Q_{0}$ and $b$.

The Freundlich isotherm (Eq. 3)(22) can be applied for non-ideal sorption on heterogeneous surfaces and multilayer sorption. It also assumes that the adsorbent has a different affinity for adsorption. The Freundlich equation is expressed as:

$$
q_{e}=K_{F} C_{e}^{\frac{1}{n_{n}}}
$$


where $K_{F}$ and $n$ are Freundlich constants indicating adsorption capacity (mg/kg) and intensity or the favorability of the sorption process, respectively. To determine the constants $K_{F}$ and $n$, the Freundlich equation can be described by the linearized form:

$$
\log Q_{e}=\log _{F}+\frac{1}{n} \log C_{e}
$$

Values of $K_{F}$ and $n$ are calculated from the intercept and slope of the linear plots of $\log q_{e}$ vs. $\log C_{e}$.

Statistical analysis: All statistical analyses were performed using MS. Excel and Minitab17 computer programs.

\section{Results and Discussion}

Physical and chemical properties of the soils: Results of analyses are given in Table 2. Soil textures of the studied soils were silt loam, silty clay loam, silty clay, silty clay, silt loam and silt loam for Sara, Gopalpur, Ishurdi, Ghatail, Sonatala and Belabo, respectively. Sara, Gopalpur and Ishurdi soil series were developed from calcareous parent materials and $\mathrm{pH}$ values of these soil series were 7.69, 7.59 and 7.1, respectively. Ghatail, Sonatala and Belabo soil series are non-calcareous in nature and $\mathrm{pH}$ values were between 5.2 and 6.4 in these soils. Organic matter content was very low in Sara, Ishurdi, Sonatala and Belabo series, ranging from 0.68 to $1.01 \%$. Gopalpur and Ghatail soil series possessed 2.16 and $1.73 \%$ organic matter, respectively, which are moderate in amounts. Cation exchange capacities of the investigated soils ranged from 4.48 to $12.19 \mathrm{cmol}(+) / \mathrm{kg}$. Free $\mathrm{CaCO}_{3}$ contents of Ghatail, Sonatala, and Belabo soil series were not determined; in other soils, it varied from 3.85 to $7.06 \%$. Available phosphorus in the studied soils ranged from 4.16 to $48.75 \mu \mathrm{g} / \mathrm{g}$. Total $\mathrm{P}$ and total $\mathrm{K}$ varied from 342 to 1157 and 5801 to $9994 \mu \mathrm{g} / \mathrm{g}$, respectively. Total Mn content was the highest in Belabo soil series $(618 \mu \mathrm{g} / \mathrm{g})$ and the lowest in Gopalpur soil series (377 $\mu \mathrm{g} / \mathrm{g}$ ). Total Fe content ranged from 15866 to 38717 $\mu \mathrm{g} / \mathrm{g}$ in the calcareous soils. Total Fe content in the noncalcareous soils differed from 4691 to $6708 \mu \mathrm{g} / \mathrm{g}$. Free iron oxide, amorphous iron, and organically bound iron were in the ranges of 3779 to 7247,781 to 3613 and 292 to $2006 \mu \mathrm{g} / \mathrm{g}$, respectively.

Phosphate sorption: Data from isotherm experiments were plotted for calcareous and non-calcareous soils by plotting the amount of phosphate sorbed ( $\left.\mathrm{P}_{\text {sorb }}\right)$ against the equilibrium concentration of phosphate $\left(\mathrm{P}_{\text {eq }}\right)$. The data were further used for fitting into Langmuir and Freundlich isotherm models.

Phosphate sorption efficiency: The added phosphate was sorbed by the calcareous and non-calcareous soils and the amount and percentage of phosphate sorption varied at all the rates. However, when no phosphate was added to the soils, i.e. at $0 \mu \mathrm{g} P / \mathrm{ml}$, some desorption was noticed in all the soils. This phenomenon was reported by other scientists 
working with calcareous and non-calcareous soils ${ }^{(23,24,25)}$. In the calcareous soils, phosphate sorption increased gradually up to $100 \mu \mathrm{g} \mathrm{PO}_{4^{3}-\mathrm{P}} / \mathrm{ml}$ and beyond that concentration, the amount of sorption decreased substantially. This finding is in contrast to the findings of Leytem and Westermann ${ }^{(26)}$. In their study, there was a sharp increase

Table 2. Physical and chemical properties of soils. Differences were determined by one-way ANOVA followed by Tukey's pairwise comparison. Different letters in the same row indicate significant differences between different soils $(p<0.05)$.

\begin{tabular}{|c|c|c|c|c|c|c|}
\hline \multirow[t]{2}{*}{ Properties } & \multicolumn{6}{|c|}{ Series } \\
\hline & Sara & Gopalpur & Ishurdi & Ghatail & Sonatala & Belabo \\
\hline Sand (\%) & 30 & 12 & 1 & 5 & 15 & 15 \\
\hline Silt (\%) & 53 & 56 & 51 & 51 & 66 & 70 \\
\hline Clay (\%) & 17 & 32 & 48 & 44 & 19 & 15 \\
\hline Textural class & Silty loam & Silty clay loam & Silty clay & Silty clay & Silty loam & Silty loam \\
\hline $\mathrm{pH}$ & 7.7 & 7.6 & 7.1 & 6.4 & 5.7 & 5.2 \\
\hline $\begin{array}{l}\text { Organic carbon } \\
(\%)\end{array}$ & $0.68 \pm 0.12 \mathrm{e}$ & $2.16 \pm 0.07 \mathrm{a}$ & $1.01 \pm 0.07 \mathrm{c}$ & $1.73 \pm 0.07 \mathrm{~b}$ & $0.84 \pm 0.07 d$ & $0.80 \pm 0.01 d$ \\
\hline $\begin{array}{l}\text { Free carbonate } \\
(\%)\end{array}$ & 7.06 & 3.85 & 5.78 & - & - & - \\
\hline $\begin{array}{l}\text { CEC } \\
(\mathrm{cmol}(+) / \mathrm{kg}\end{array}$ & $6.53 \pm 0.36 b c$ & $8.83 \pm 1.05 b$ & $12.19 \pm 4.02 \mathrm{a}$ & $7.47 \pm 0.54 b c$ & $4.48 \pm 0.24 c$ & $4.64 \pm 1.30 c$ \\
\hline Total P (\%) & $0.116 \pm 0.007 a$ & $0.070 \pm 0.013 b$ & $0.059 \pm 0.005 b c$ & $0.038 \pm 0.002 \mathrm{~cd}$ & $0.077 \pm 0.006 b$ & $0.034 \pm 0.012 c$ \\
\hline $\begin{array}{l}\text { Available P } \\
\left(\mu \mathrm{g} \mathrm{g}^{-1}\right)\end{array}$ & $35.83 \pm 3.82 \mathrm{ab}$ & $34.17 \pm 7.64 \mathrm{a}$ & $25.83 \pm 2.89 \mathrm{~b}$ & $4.17 \pm 0.83 c$ & $10.00 \pm 0.00 c$ & $48.33 \pm 1.91 \mathrm{a}$ \\
\hline Total Mn (\%) & $0.038 \pm 0.003 b$ & $0.039 \pm 0.007 \mathrm{~b}$ & $0.042 \pm 0.002 b$ & $0.051 \pm 0.002 \mathrm{ab}$ & $0.038 \pm 0.007 \mathrm{~b}$ & $0.062 \pm 0.014 \mathrm{a}$ \\
\hline Total Fe (\%) & $1.59 \pm 0.15 \mathrm{~d}$ & $2.84 \pm 0.25 b c$ & $3.87 \pm 0.33 a$ & $3.47 \pm 0.05 \mathrm{ab}$ & $2.54 \pm 0.36 c$ & $1.12 \pm 0.37 \mathrm{~d}$ \\
\hline $\begin{array}{l}\text { Free iron oxide } \\
(\mu \mathrm{g} / \mathrm{g})\end{array}$ & $3779 \pm 132 \mathrm{e}$ & $6937 \pm 119 c$ & $10128 \pm 140 a$ & $7793 \pm 222 b$ & $4691 \pm 187 d$ & $6832 \pm 14 c$ \\
\hline $\begin{array}{l}\text { Amorphous Fe } \\
(\mu \mathrm{g} / \mathrm{g})\end{array}$ & $781 \pm 70 \mathrm{e}$ & $2397 \pm 141 d$ & $2248 \pm 112 d$ & $4723 \pm 102 a$ & $2904 \pm 130 c$ & $3296 \pm 131 b$ \\
\hline $\begin{array}{l}\text { Organically } \\
\text { bound Fe }(\mu \mathrm{g} / \mathrm{g})\end{array}$ & $292 \pm 14 d$ & $433 \pm 23 c d$ & $909 \pm 39 b c$ & $1066 \pm 48 b$ & $2006 \pm 176 a$ & $835 \pm 83 b c$ \\
\hline
\end{tabular}

in the slope of the curve at equilibrium concentrations greater than $150 \mu \mathrm{g} \mathrm{PO}_{4}^{3-} \mathrm{P} / \mathrm{ml}$. They attributed this increase to the precipitation process associating $\mathrm{Ca}$ and $\mathrm{P}$. In the noncalcareous soils, in the present study, the amount of $\mathrm{P}$ sorption progressively increased with increasing $\mathrm{P}$ application; this trend is in line with the findings of Naseri and his coworkers ${ }^{(27)}$. The percentage of sorption ranged from 18.0 to $60.8 \%$ in Sara soil series, the lowest being at the highest loading and the highest at $25 \mu \mathrm{g} / \mathrm{ml} \mathrm{PO} 4^{3-} \mathrm{P}$. In Gopalpur soil series, the percentage of sorption varied from 17.1 to 74.6. In Ishurdi soil series, the 
percentage of sorption decreased gradually with an increase in phosphate loading concentration (63.3 to 18.6). A similar kind of phenomenon was reported by other scientists in Ishurdi soil series(23). On the other hand, the non-calcareous soils exhibited varying sorption capacities. The development of soils on different parent materials can be accounted for the observed phenomena. The percentage of sorption ranged from 26.0 to 79.6 in Ghatail soil series, the lowest being at the highest loading and the highest at 10 $\mu \mathrm{g} / \mathrm{ml} \mathrm{PO}_{4}{ }^{3-}-\mathrm{P}$. In Sonatala soil series, the percentage of sorption varied from 25.6 to 92.5 . The percentage of sorption decreased gradually with an increase in phosphate loading concentration (63.3 to 27.8) in Belabo soil series.

The isotherms constructed (Figs 1 and 2) using the experimental data exhibit that they conformed to the L-curve isotherm type. It is an indication of the strong affinity between soil constituents and the phosphate ions, particularly at lower concentrations of phosphate ${ }^{(28)}$. All the calcareous soil series behaved similarly exhibiting an increased $\mathrm{P}$ sorption with an increase in P application up to $100 \mu \mathrm{g} / \mathrm{ml}$. At the highest loading (150 $\mu \mathrm{g} / \mathrm{ml}), \mathrm{P}$ sorption decreased in all the soils. This phenomenon can be explained by looking into two mechanisms whereby phosphate anions get adsorbed onto soil micelles. Phosphate adsorption takes place through specific and non-specific adsorption processes. Specific adsorption is related to high-affinity adsorption sites and micropore diffusion adsorption $29,30,31)$, whereas non-specific adsorption is associated with low-affinity sites. While specific adsorption is preponderant during the fast adsorption stage, non-specific adsorption predominates during the slow adsorption stage. The percentage of adsorption via non-specific adsorption process increases when phosphate loading increases ${ }^{(32)}$. In the present study, at $150 \mu \mathrm{g} / \mathrm{ml} \mathrm{PO}_{4}{ }^{3-}-\mathrm{P}$ application, phosphate sorption decreased in all the

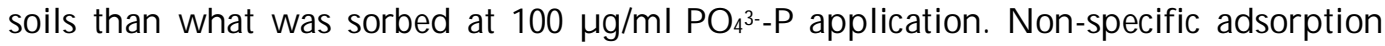
process might have played apredominant role for the additional $\mathrm{P}$ when $\mathrm{P}$ application was increased from 100 to $150 \mu \mathrm{g} / \mathrm{ml}$. Therefore, even though the amount of P sorption was higher during the fast-adsorption stage at higher loading $(150 \mu \mathrm{g} / \mathrm{ml})$, in the slow adsorption process the phosphate was initially adsorbed and then desorbed (the adsorption experiment was run for $72 \mathrm{hrs}$ ). As a result, more phosphate was sorbed at $100 \mu \mathrm{g} / \mathrm{ml}$ than $150 \mu \mathrm{g} / \mathrm{ml} \mathrm{PO}^{3--} \mathrm{P}$ application. Comparing the experimental highest amount of $\mathrm{P}$ sorbed in these soil series, it is evident that each soil series has a different capacity to sorb P. Gopalpur soil series $(743.33 \mu \mathrm{g} / \mathrm{g}$ ) had the highest value of maximum adsorption, followed by Sara soil series $(700 \mu \mathrm{g} / \mathrm{g})$ and Ishurdi soil series $(637.04 \mu \mathrm{g} / \mathrm{g})$. On the other hand, in the non-calcareous soil series, Sonatala soil series had the highest value of maximum adsorption $(869.89 \mu \mathrm{g} / \mathrm{g})$, followed by Ghatail soil series $(781.43 \mu \mathrm{g} / \mathrm{g})$ and Belabo soil series (464.53 $\mu \mathrm{g} / \mathrm{g}$ ).

Phosphate sorption isotherms: The sorption isotherm data of $\mathrm{P}$ was modeled into the Langmuirand Freundlich equations. The goodness of the fit of the models was checked by the coefficient of variation $\left(R^{2}\right)$ values. When the Langmuir equation applied to the 
experimental data, all the soils showed a good fit except Sonatala soil series (Fig. 3, Table 3). $R^{2}$ value was the highest in the Ishurdi soil, followed by Gopalpur and Ghatail, Belabo, Sara and Sonatala. Sorption parameters were calculated from the Langmuir and Freundlich equations (Table 4 ). The maximum amount of sorbate sorbed by the soil ( $Q_{0}$ ) was calculated for all the soils and Sonatala was found to sorb the highest amount of $\mathrm{P}$ from the solution according to the Langmuir equation. However, since the model did not

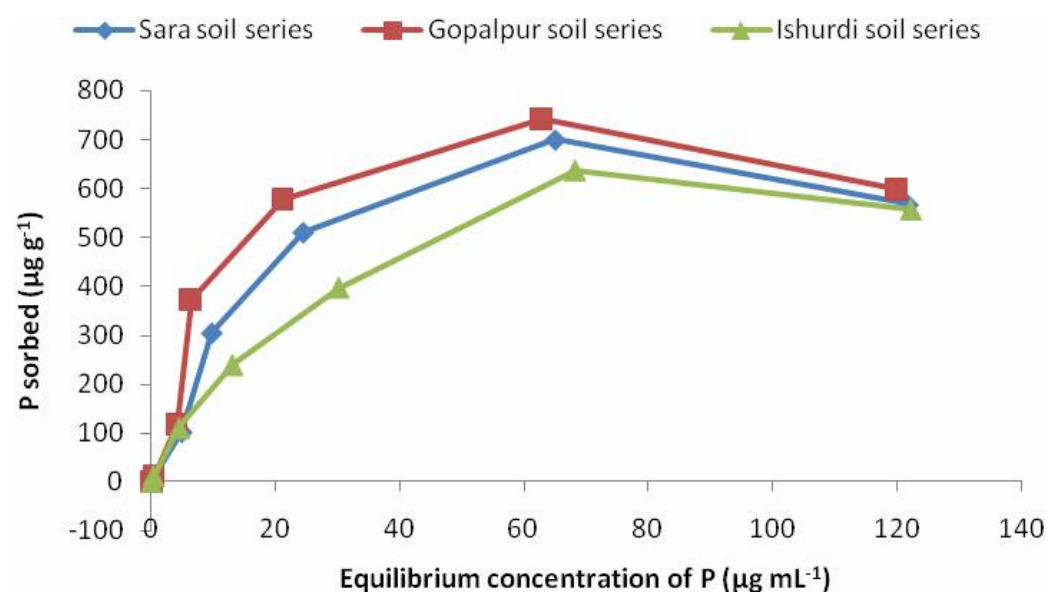

Fig. 1. Phosphate sorption isotherm of calcareous soils.

$\multimap$ Ghatail soil series $\rightarrow$ Sonatala soil series $\rightarrow$ Belabo soil series

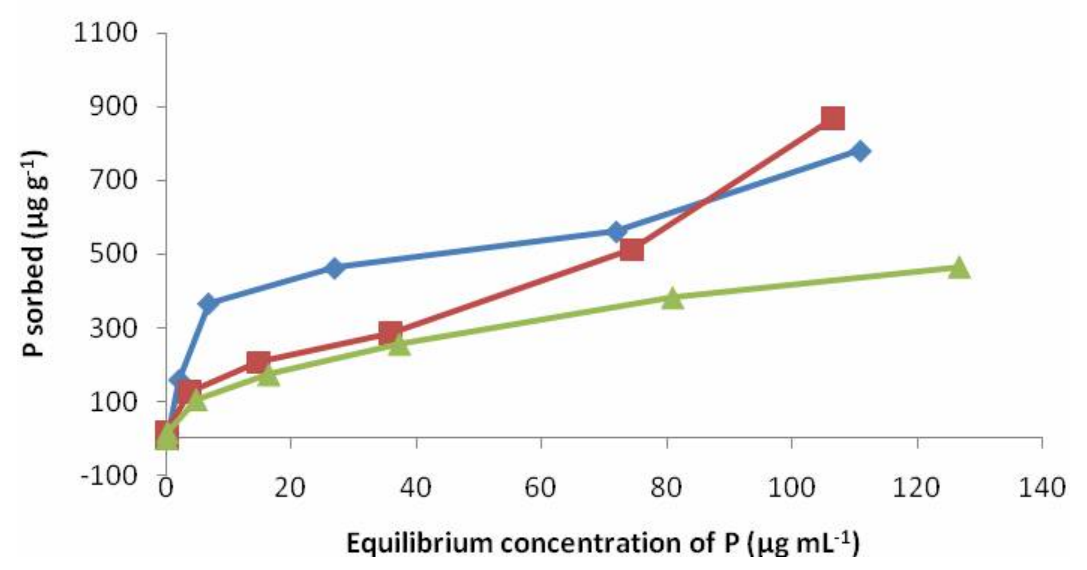

Fig. 2. Phosphate sorption isotherm of non-calcareous soils.

fit well into the experimental data from Sonatala soil, that quantity was not considered for comparing calcareous and non-calcareous soils in terms of their Langmuir modelderived maximum sorption capacities. It is worth mentioning that the $Q_{0}$ value is an 
empirical curve-fitting parameter and is not necessarily the true sorption maxima ${ }^{(3)}$. In this study, the input concentrations were not sufficient for some soils. Reduced P levels were chosen to simulate most soil environments and are also useful for determining the soil $\mathrm{P}$ requirement in the lower concentration range ${ }^{(3)}$. Values of Langmuir sorption maximum $\left(Q_{0}\right)$ for these soils ranged from 526 to $769 \mu \mathrm{g} / \mathrm{g}$ (Sonatala soil's data was not used). However, the Langumir equation-derived maximum sorption capacities overestimated the experimental data. According to the Langmuir equation, the amount of phosphate sorbed followed the order: Ghatail $>$ Sara $=$ Gopalpur $>$ Ishurdi $>$ Belabo. On the other hand, in the actual study maximum phosphate sorption followed the following order: Sonatala $>$ Ghatail $>$ Gopalpur $>$ Sara $>$ Ishurdi $>$ Belabo .

The highest sorption capacity of Sonatala soil series could be attributed to its organically bound iron, amorphous iron content, and $\mathrm{pH}$. Sonatala soil had a $\mathrm{pH}$ value of 5.7 which was lower than the soils having comparable organically bound and amorphous iron content. The lower $\mathrm{pH}$ value and iron fractions in the soil might have worked in concert in removing the applied phosphate from the solution. Belabo soil series possessed the lowest amount of total iron content and accordingly the sorption capacity was the lowest in that soil series. Among the calcareous soils, Gopalpur was found to sorb more phosphate from the other two soil series. Despite having the lowest amount of total iron content among the calcareous soils, Gopalpur had more amorphous iron oxide than the other two soils. This feature can be accounted for the highest sorption potential of Gopalpur soil series among the calcareous soil series.

The Langmuir constant $b$ is related to the affinity of the binding sites, i.e. the bonding energy of $\mathrm{P}$ sorption and ranges from 0.027 to $0.088 \mathrm{~L} / \mathrm{mg}$. Varied values of $b$ indicate that the bonding energy of $\mathrm{P}$ sorption is different for the studied soil series. The binding energy was the highest for Sara soil series $(0.105 \mathrm{~L} / \mathrm{mg})$, followed by Gopalpur $(0.0880$ $\mathrm{L} / \mathrm{mg})$, Ghatail $(0.078 \mathrm{~L} / \mathrm{mg} \mathrm{P})$, Ishurdi $(0.050 \mathrm{~L} / \mathrm{mg})$, Belabo $(0.043 \mathrm{~L} / \mathrm{mg})$ and Sonatala $(0.027 \mathrm{~L} / \mathrm{mg})$. The binding energy values for the noncalcareous soils and one of the calcareous soils (Ishurdi series) are below the threshold value of $0.07 \mathrm{~L} / \mathrm{mg}$ proposed by Mcdowell(33). Soils having less than this value of binding strength are subject to enhanced loss of $\mathrm{P}$ through surface and subsurface flows. Thus, the studied calcareous soils are less susceptible to phosphate loss via surface runoff and other avenues. Even though the noncalcareous soils have sorbed more phosphate, they do not bind phosphate strongly, thereby predisposing the soils to lose more phosphate compared to calcareous soils. Therefore, fertilizer should be applied to these soils judiciously so that applied phosphate does not find its way into the nearby water bodies posing environmental concerns.

The adsorption isotherms were also examined by the linear form of the Freundlich adsorption equation by plotting $\log q_{e}$ against $\log C_{e}$ (Fig. 4, Table 3), and all the soils showed a good fit except Gopalpur and Ghatail soil series. The $\mathrm{R}^{2}$ values for the Freundlich model with Belabo, Sonatala and Ishurdi soil series indicated a good fit 


\section{Sara}

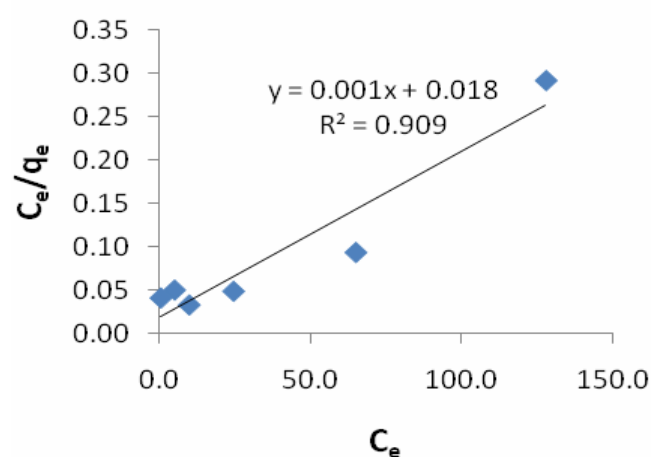

Ishurdi

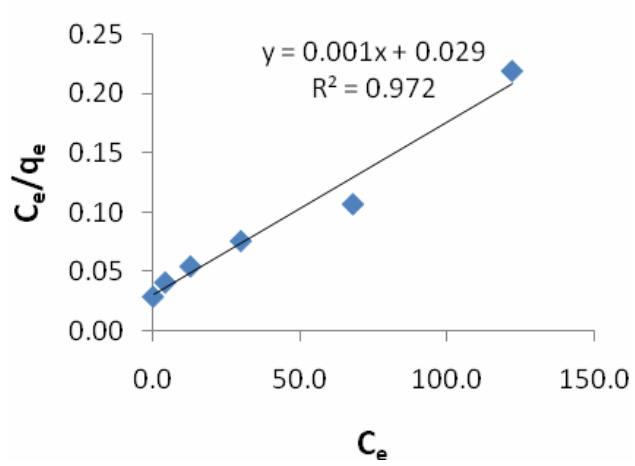

Sonatala

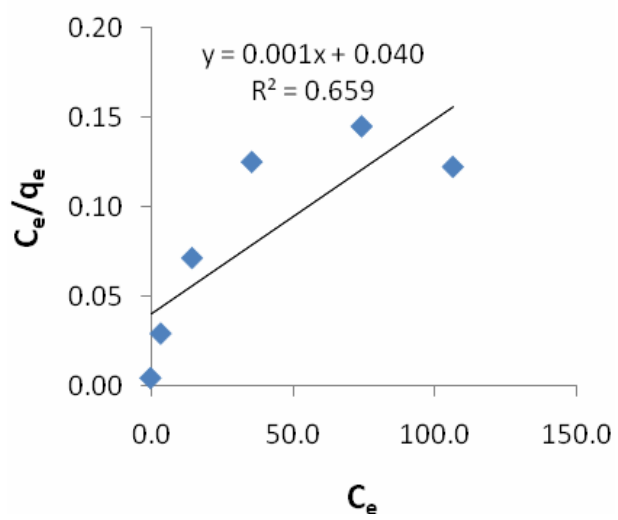

Gopalpur

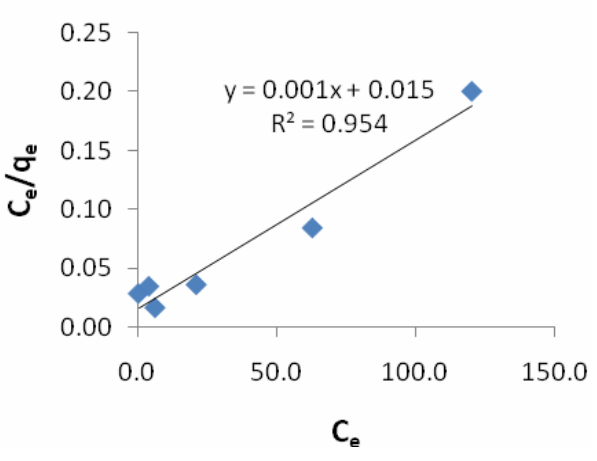

Ghatail

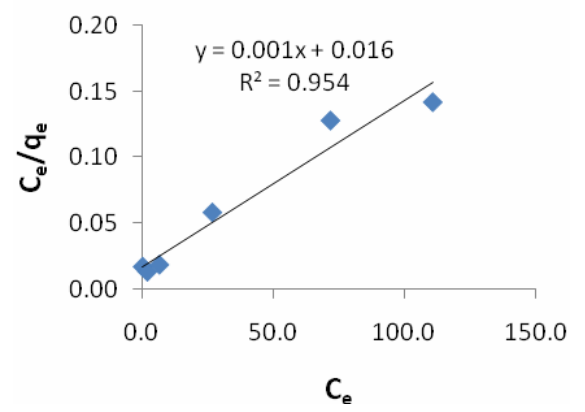

$C_{e}$

\section{Belabo}

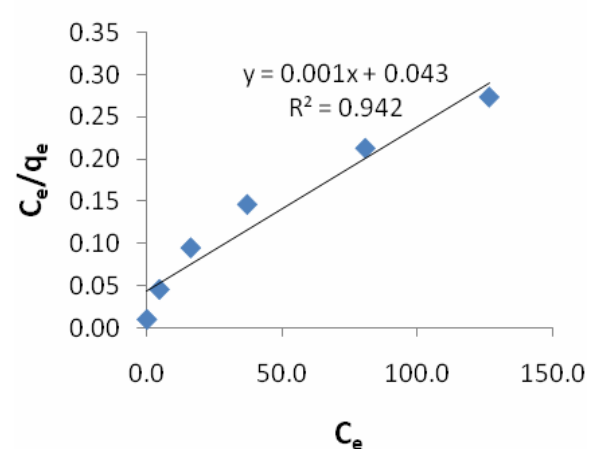

Fig. 3. Adsorption isotherms fitted to Langmuir equation. 
between the experimental and isotherm data. The $\mathrm{R}^{2}$ value was the highest in Belabo soils series (0.9976), followed by Sonatala (0.9785), Ishurdi (0.9636), Sara (0.9088), Ghatail (0.8835) and Gopalpur (0.8570). Sorption parameters were also calculated from the Freundlich equation (Table 4). Freundlich isotherm describes sorption behavior better when heterogeneity is present in the adsorbents ${ }^{(34,35)}$. In the present study, data conformed to Langmuir equation more meaning the soils possessed energetically homogeneous surface which is unlikely to happen. However, as phosphate is known to be chemisorbed by a select metal sites, this phenomenon can occur. If the putative metal sites are uniformly distributed on the soil particles, a virtually homogeneous surface is possible. This could be a plausible explanation for the phosphate adsorption data following the Langmuir equation.

The Freundlich value $\left(\mathrm{K}_{\mathrm{f}}\right)$ provides an indication of the average sorption capacity of the soil. In other words, the coefficient is a measure of the amount of P sorption sites. In the studied soils, the $\mathrm{K}_{\mathrm{f}}$ values ranged from 30.13 to $63.02 \mu \mathrm{g} / \mathrm{g}$. According to Freundlich parameter $\mathrm{K}_{\mathrm{f}}$, Ghatail soil has the highest sorption sites followed by Sonatala, Gopalpur, Belabo, Ishurdi, and Sara. The slope $1 / \mathrm{n}$ being 1 indicates that sorption carried out over the range of chemical concentrations used in the experiment is not affected by the concentration of the chemical in solution. A slope less than 1 indicates that there is proportionally more chemical sorbed when the concentration is low and less chemical is sorbed when the concentration is high. The calculated values of $1 / \mathrm{n}$ are indicating that the soils in question sorbed more phosphate over the range of low concentrations. The highest $1 / \mathrm{n}$ was found in Sara soil series (0.7487), followed by Gopalpur (0.6903), Ishurdi (0.6843), Ghatail (0.5891), Belabo (0.4993), and Sonatala (0.4940).

Table 3. Fitted Langmuir and Freundlich equations using sorption data from studied soil series.

\begin{tabular}{|c|c|c|c|c|}
\hline \multirow{2}{*}{$\begin{array}{l}\text { Soil } \\
\text { series }\end{array}$} & \multicolumn{2}{|c|}{ Langmuir equation } & \multicolumn{2}{|c|}{ Freundlich equation } \\
\hline & Equation & $\mathrm{R}^{2}$ value & Equation & $R^{2}$ value \\
\hline Sara & $y=0.0019 x+0.0181$ & 0.9094 & $y=0.7487 x+1.4790$ & 0.9088 \\
\hline Gopalpur & $y=0.0014 x+0.0159$ & 0.9541 & $y=0.6903 x+1.6478$ & 0.8570 \\
\hline Ishurdi & $y=0.0015 x+0.0298$ & 0.9720 & $y=0.6843 x+1.5107$ & 0.9636 \\
\hline Ghatail & $y=0.0013 x+0.0166$ & 0.9543 & $y=0.5891 x+1.7995$ & 0.8835 \\
\hline Sonatala & $y=0.0011 x+0.0402$ & 0.6597 & $y=0.4940 x+1.7989$ & 0.9785 \\
\hline Belabo & $y=0.0019 x+0.0439$ & 0.9423 & $y=0.4993 x+1.6315$ & 0.9976 \\
\hline
\end{tabular}

Maximum phosphorus buffering capacity (MPBC): The maximum phosphorus buffering capacity (MPBC) is a product of the Langmuir model $Q_{0}$ and ${ }^{b}$ (36). It is a useful estimate of the P supplying and immobilization capacities and rates by soils(36,37). The MPBC is regarded as an inherent property of soils. The MPBC values shown in Table 4 indicate 
that Sonatala, Belbao amd Ishurdi will need less P fertlization compared to other soils having higher values of MPBC. Therefore, farmers will be able to maintain an optimum concentration of phosphorus for crop growth in those three soils with less capital(38).
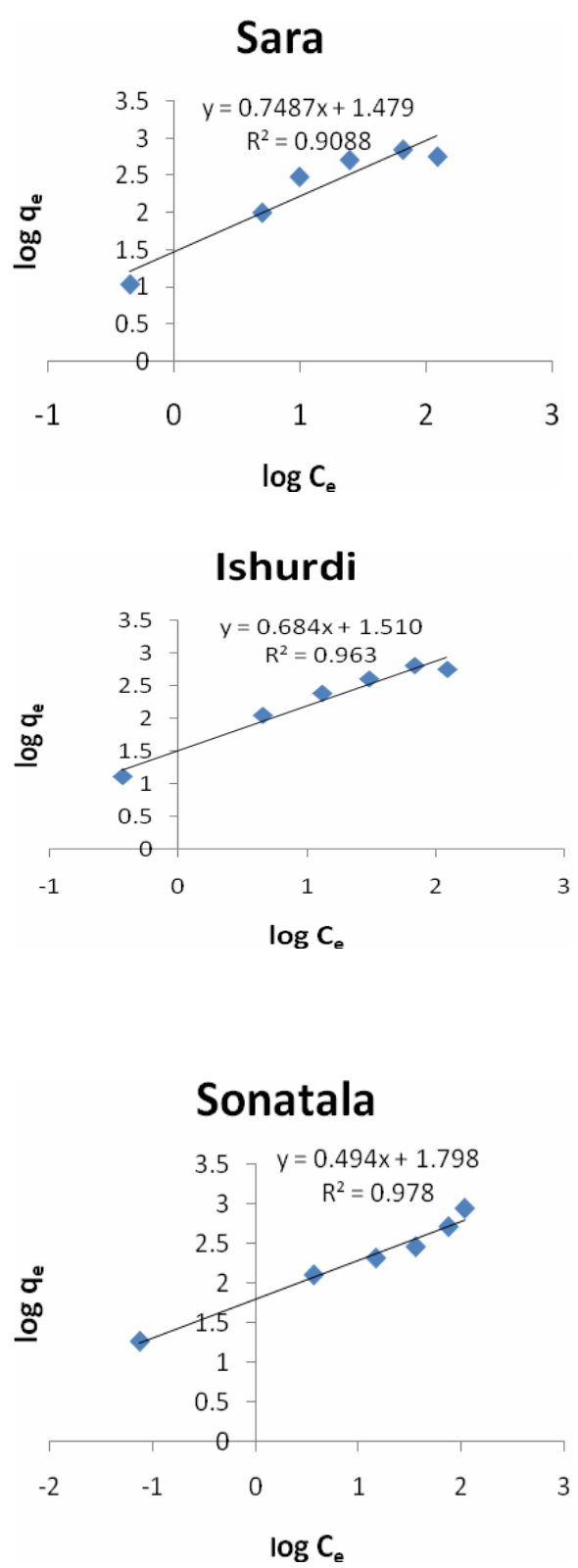
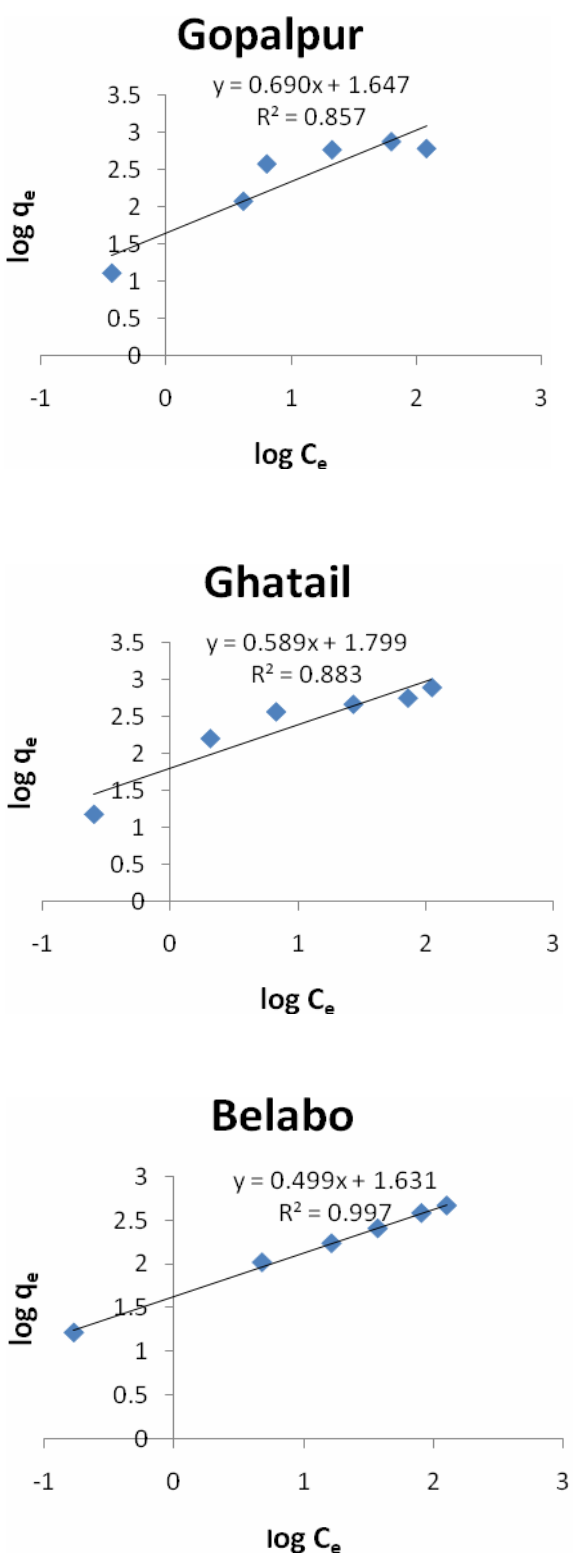

Fig. 4. Adsorption isotherms fitted to Freundlich equation. 
Standard phosphate requirement (SPR): Sorption equations were used to determine the soil phosphorus requirement (SPR), which is the $\mathrm{P}$ required to maintain a predetermined $\mathrm{P}$ concentration in solution(6). Soil $\mathrm{P}$ requirements were calculated by plugging in the desired $\mathrm{P}$ concentration into the fitted sorption equations. Desired P concentrations, however, depend on the intended land use. For example, if someone wants to use their land for crop production purposes, a value of $0.2 \mathrm{mg} \mathrm{P} \Lambda$ is regarded as an appropriate value $^{(39)}$. Since $\mathrm{P}$ is a nutrient contaminant in waterbodies, other levels of $\mathrm{P}$ are also used for the calculation of soil $\mathrm{P}$ requirements. For instance, the USEPA recommended a maximum level of $1 \mathrm{mg} \mathrm{P} /$ in surface runoff $(9)$.

Table 4. Sorption parameters derived from Langmuir and Freundlich equations.

\begin{tabular}{|c|c|c|c|c|c|}
\hline \multirow[b]{2}{*}{ Soil series } & \multicolumn{3}{|c|}{ Langmuir equation } & \multicolumn{2}{|c|}{ Freundlich equation } \\
\hline & $Q_{0}(\mathrm{mg} / \mathrm{kg})$ & $b(1 / m g)$ & MPBC $(1 / \mathrm{kg})$ & $K_{F}$ & $\frac{1}{n}$ \\
\hline Sara & 526 & 0.105 & 55.2 & 30.13 & 0.7487 \\
\hline Gopalpur & 714 & 0.088 & 62.8 & 44.44 & 0.6903 \\
\hline Ishurdi & 667 & 0.050 & 33.4 & 32.41 & 0.6843 \\
\hline Ghatail & 769 & 0.078 & 60.0 & 63.02 & 0.5891 \\
\hline Sonatala & 909 & 0.027 & 24.5 & 62.94 & 0.4940 \\
\hline Belabo & 526 & 0.043 & 22.6 & 42.81 & 0.4993 \\
\hline
\end{tabular}

Soil $\mathrm{P}$ requirements at 0.2 and $1.0 \mathrm{mg} \mathrm{P} /$ were determined using Langmuir and Freundlich equations (Table 5). The models generated slightly different SPR values. As Langmuir equation fitted well into sorption data for Sara, Gopalpur, Ishurdi and Ghatail soil series, Langmuir equation-derived values were used to estimate soil P requirements for these soil series. For Sonatala and Belabo soil series, Freundlich-equation derived values were used for soil P requirements. To attain $0.2 \mathrm{mg} \mathrm{P} /$ in the soil solution, SPR values ranged from $27-44 \mathrm{mg} / \mathrm{kg}$ for calcareous soils. Afsar and Hossain ${ }^{(40)}$ previously worked with calcareous soils in Bangladesh and reported SPR values between 19 and 44 $\mathrm{mg} / \mathrm{kg}$. Samadi(41) also worked with calcareous soils in Iran and according to his calculations, SPR values were within a range of $5-114 \mathrm{mg} / \mathrm{kg}$ to maintain a soil solution concentration of $0.2 \mathrm{mg} \mathrm{P} \Lambda$. For non-calcareous soils, soil $\mathrm{P}$ requirements ranged from 19 - $43 \mathrm{mg} / \mathrm{kg}$. Soil P requirements to reach $1 \mathrm{mg} \mathrm{P} /$ were 32, 56 and $58 \mathrm{mg} \mathrm{P} / \mathrm{kg}$ for Ishurdi, Ghatail and Gopalpur soils, respectively. For Sara, Sonatala and Belabo soils, the soil $\mathrm{P}$ requirements were 30, 63 and $43 \mathrm{mg} / \mathrm{kg}$. In the present study, calcareous and noncalcareous soils did not differ in terms of soil phosphorus requirements.

Correlation between phosphate sorption coefficient and soil properties: In order to elucidate the mechanism of phosphate sorption in the studied soils, Pearson correlation coefficients 
were calculated between the various parameters of the phosphate sorption isotherms and soil properties which are thought to be responsible for phosphate sorption. However, it was done with a caveat that such correlations might not always indicate causality. No significant relationship was found between the clay content and the phosphate sorption at $100 \mu \mathrm{g} / \mathrm{ml}$ of $\mathrm{P}$ application. The findings agree with the results of Ayodole and Agboola ${ }^{(42)}$.

Table 5. Soil $P$ requirements $\left(P_{\text {req }}\right)$ in $\mathrm{mg} / \mathrm{kg}$ to reach 0.2 and $1.0 \mathrm{mg} / \mathrm{l}$ in equilibrium solution as determined by isotherm equations.

\begin{tabular}{|c|c|c|c|c|}
\hline \multirow{3}{*}{ Soil series } & \multicolumn{4}{|c|}{ Soil $\mathrm{P}$ requirement to reach desired concentration $(\mathrm{mg} /)$} \\
\hline & \multicolumn{2}{|c|}{ Langmuir } & \multicolumn{2}{|c|}{ Freundlich } \\
\hline & 0.2 & 1.0 & 0.2 & 1.0 \\
\hline Sara & 36 & 50 & 9 & 30 \\
\hline Gopalpur & 44 & 58 & 15 & 44 \\
\hline Ishurdi & 27 & 32 & 11 & 32 \\
\hline Ghatail & 43 & 56 & 24 & 63 \\
\hline Sonatala & 22 & 24 & 28 & 63 \\
\hline Belabo & 19 & 22 & 19 & 43 \\
\hline
\end{tabular}

However, many other scientists reported a positive correlation between clay contents and sorption maximum ${ }^{(6,24)}$. A statistically significant relationship $\left(\mathrm{R}^{2}=0.952 ; \mathrm{p}=0.001\right)$ was found between $\mathrm{pH}$ and phosphate sorbed at $100 \mu \mathrm{g} / \mathrm{ml} \mathrm{PO}_{4}{ }^{3-}-\mathrm{P}$ application. Significant relationships were also found between $\mathrm{pH}$ and Freundlich exponent $(1 / \mathrm{h})\left(\mathrm{R}^{2}=0.945, \mathrm{p}=\right.$ 0.001). The positive relationship between $\mathrm{pH}$ and Freundlich exponent indicates that proportionally more phosphorus is sorbed as $\mathrm{pH}$ increases. No statistically significant relation was found between the organic matter content and the amount of phosphate sorption in the studied soils.

\section{Conclusions}

In the present investigation, some calcareous and non-calcareous soils were studied to determine the effects of calcareousness on phosphate sorption indices which are important quantities from agricultural and environmental perspectives. Adsorption experiments' data were modeled into Langmuir and Freundlich isotherms to derive the phosphate sorption indices. Langmuir and Freundlich equations produced different values for soil $\mathrm{P}$ requirements (SPR) at 0.2 and $1.0 \mathrm{mg} \mathrm{P}$. In general, calcareous soils showed higher maximum phosphorus buffering capacity (MPBC) indicating that they will need less $\mathrm{P}$ fertilization compared to non-calcareous soils. For two of the three calcareous soils, the Langmuir equation-derived constant $b$ values were higher than 0.07 
$1 / \mathrm{mg}$. Therefore, higher bonding energy of P sorption for calcareous soils makes them less vulnerable to loss via surface runoff.

\section{References}

1. Cornel P and C Schaum 2009. Phosphorus recovery from wastewater: Needs, technologies and costs. Water Science and Technology 59(6): 1069-1076.

2. Cordell D, A Rosemarin, JJ Schroder and AL Smit 2011. Towards global phosphorus security: a systems framework for phosphorus recovery and reuse options. Chemosphere 84(6): 747758.

3. Angelo E, M Vandiviere, W Thom and F Sikora 2003. Estimating soil phosphorus requirements and limits from oxalate extract data. Journal of Environmental Quality 32(3):1082-8.

4. Sims JT, RR Simard and BC Joern 1998. Phosphorus loss in agricultural drainage: historical perspective and current research. Journal of Environmental Quality 27(2): 277-293.

5. Beck MA and PA Sanchez 1994. Soil phosphorus fraction dynamics during 18 years of cultivation on a typic paleudult. Soil Science Society of America Journal 58(5): 1424-1431.

6. Dodor DE and K Oya 2000. Phosphate sorption characteristics of major soils in Okinawa, Japan. Communications in Soil Science and Plant Analysis 31(3-4):277-288.

7. Fox RL and EJ Kamprath 1970. Phosphate sorption isotherms for evaluating the phosphate requirements of soils. Soil Science Society of America Proceedings 34: 902-907.

8. Beckwith RS 1965. Sorbed phosphate at standard supernatant concentration as an estimate of the phosphate needs of soils. Australian Journal of Experimental Agriculture and Animal Husbandary 5(16): 52-58.

9. USEPA 1995. Ecological restoration: A tool to manage stream quality.

10. FAO NNDP 1988. Land resources appraisal of bangladesh for agricultural development 2 FAO, Rome.

11. Day PR 1965. Particle fractionation and particle size analysis. In: C. A. Black (Ed.), Methods of Soil Analysis. Part 1. Agronomy Monograph 9, ASA and SSSA.

12. Allison LE and CD Moodie 1965. Carbonate. In: C. A. Black (Ed.), Methods of Soil Analysis. Part 2: Chemical and Microbiological Properties, ASA and SSSA.

13. Walkley A 1947. A critical examination of a rapid method for determining organic carbon in soils-effect of variations in digestion conditions and of inorganic soil constituents. Soil Science 63(4):251-264.

14. Jackson ML 1958. Soil Chemical Analysis. Englewood Cliffs, N.J.: Prentice-Hall.

15. Olsen S, C Cole, F Watanabe and L Dean 1954. Estimation of available phosphorus in soils by extraction with sodium bicarbonate. In: U. S. D. o. Agriculture.

16. Bray R and L Kurtz 1945. Determination of total, organic and available forms of phosphorus in soils. Soil Science 50: 39-45.

17. Murphy J and J Riley 1962. A modified single solution method for determination of phosphate in natural water. Analytica Chimica Acta 27: 495-501.

18. Holmgren G 1967. A rapid citrate-dithionite extractable iron procedure. Soil Science Society of America Proceedings 31:210-211. 
19. Schwertmann U 1964. Differenzierung der eisenoxide des bodens durch extracktion mit ammoniumoxalat. L ö sung. Z. Planz. D ü ng. Bodenk. 105:194-202.

20. Nair PS, TJ Logan, AN Sharpley, LE Sommers, MA Tabatabai and TL Yuan 1984. Interlaboratory comparison of a standardized phosphorus adsorption procedure. Journal of Environmental Quality 13(4): 591-595.

21. Langmuir I 1918. The adsorption of gases on plane surfaces of glass, mica and platinum. Journal of the American Chemical Society 40: 1361-1403.

22. Freundlich H 1906. Concerning adsorption in solutions. zeitschrift fur physikalische chemie-Stochiometrie Und Verwandtschaftslehre 57(4): 385-470.

23. Hossain ME, S Hoque and KT Osman 2012. Phosphate sorption in some representative soils of Bangladesh. Archives of Agronomy and Soil Science 58(9): 959-966.

24. Singh B and RGilkes 1991. Phosphorus sorption in relation to soil properties for the major soil types of South-Western Australia. Australian Journal of Soil Research 29(5): 603-618.

25. Vaananen R, J Hristov, N Tanskanen, H Hartikainen, M Nieminen and H Ilvesniemi 2008. Phosphorus sorption properties in podzolic forest soils and soil solution phosphorus concentration in undisturbed and disturbed soil profiles. Boreal Environment Research 13(6): 553-567.

26. Leytem AB and DT Westermann 2003. Phosphate sorption by pacific northwest calcareous soils. Soil Science 168(5): 368-375.

27. Naseri AA, Y Hoseini, H Moazed, F Abbasi and HMV Samani 2010. Determining of Soil Phosphorus Requirement with Application of Freundlich Adsorption Isotherm. Asian Journal of Agricultural Research 4(4): 226-231.

28. Azeez JO and W Van Averbeke 2011. Effect of Manure Types and Period of Incubation on Phosphorus-Sorption Indices of a Weathered Tropical Soil. Communications in Soil Science and Plant Analysis 42(18): 2200-2218.

29. Cabrera F, Pd Arambarri, L Madrid and CG Toga 1981. Desorption of Phosphate from Iron Oxides in Relation to Equilibrium Ph and Porosity. Geoderma 26(3): 203-216.

30. Strauss R, GW Brummer and NJ Barrow 1997. Effects of Crystallinity of Geothite: Ii. Rates of Sorption and Desorption of Phosphate. European Journal of Soil Science 48: 101-114.

31. Wilson G, FE Rhoton and HM Selim 2004. Modeling the Impact of Ferrihydrite on AdsorptionDesorption of Soil Phosphorus. Soil Science 169(4): 271-281.

32. Wang X, F Liu, W Tan, W Li, X Feng and DL Sparks 2013. Characteristics of Phosphate Adsorption-Desorption onto Ferrihydrite: Comparison with Well-Crystalline Fe(Hydr) Oxides. Soil Science178(1):1-11.

33. Mcdowell R, A Sharpley and P Withers 2002. Indicator to Predict the Movement of Phosphorus from Soil to Subsurface Flow. Environmental Science and Technology 36(7): 1505-1509.

34. Chitrakar R, S Tezuka, A Sonoda, K Sakane, K Ooi and T Hirotsu 2006. Phosphate Adsorption on Synthetic Goethite and Akaganeite. Journal of Colloid and Interface Science 298(2): 602-608.

35. Ogata T, S Morisada, Y Oinuma, Y Seida and Y Nakano 2011. Preparation of Adsorbent for Phosphate Recovery from Aqueous Solutions Based on Condensed Tannin Gel. Journal of Hazardous Materials 192(2): 698-703. 
36. Holford ICR 1979. Evaluation of Soil Buffering Indices. Australian Journal of Soil Research. 17(3): 495-504.

37. Agbenin JO and H Tiessen 1994. The Effects of Soil Properties on the Differential Phosphate Sorption by Semiarid Soils from Northeast Brazil. Soil Science 157(1): 36-45.

38. Reddy DD, AS Rao and M Singh 2001. Crop Residue Addition Effects on Myriad Forms and Sorption of Phosphorus in a Vertisol. Bioresource Technology 80(2): 93-99.

39. Pierzynski GM 2005. Soils and Environmental Quality. 3rd ed., Boca Raton, FL : Taylor \& Francis.

40. Afsar MZ and ME Hossain 2012. Characterization of Some Representative Calcareous Soils of Bangladesh with Respect to Soil Phosphorus Requirements. International Journal of Agricultural Research 7: 388-397.

41. Samadi A 2006. Phosphorus Sorption Characteristics in Relation to Soil Properties in Some Calcareous Soils of Western Azerbaijan Province. Journal of Agricultural Science and Technology 8: 251-264.

42. Ayodole OJ and AA Agboola 1983. Evaluation of Phosphorus in Savannah Soils of Western Nigeria under Bush Follow Systems. The Journal of Agricultural Science 101(2): 283-289.

(Manuscript received on 7 July, 2018; revised on 17 October, 2018) 